\title{
A 'THICK DESCRIPTION' OF TWO BIBLE STUDIES BY THE SOKHANYA BIBLE SCHOOL
}

\author{
Danie C van Zyl \\ Sokhanya Bible School
}

Cape Town

\section{Profile of the group}

This group consists of Xhosa speaking church leaders who are enrolled as students of the Sokhanya Bible School. This school was founded by local church leaders, together with a white DRC minister who is still the teacher, in various townships in Cape Town in 1992.

Members normally enrol as students for a two or three year period. Participants in the two Bible studies have therefore been members of the group for a period ranging from a few months to up to three years. The group meets on a weekly basis for 2 hours on a Tuesday evening in a local school. Since classes are conducted according to the principles of adult education, members are familiar with discussions and are always eager to participate. In both recorded Bible studies the leader was not the normal teacher but one of the students, elected by the group. In this regard the situation was somewhat abnormal, but this does not seem to have hampered the flow of the discussion.

The members of the group come from a number of townships in the Nyanga-Gugulethu area. Some are old residents of the area while some are relative newcomers. Some live in formal housing units and others in squatter areas with poor infrastructure and transport facilities. Some are retired persons while others are self-employed or unskilled labourers. Educational levels vary from practical illiteracy to grade 11 . The youngest members of the group are in their mid-thirties while others are in their sixties and one is 72 . The group consists of an almost equal number of men and women.

All members occupy leadership positions in their denominations, whether as head (archbishop) or as prayer woman. Denominational affiliation covers the full spectrum of Anglicans, Methodists, Pentecostals, Ethiopians, African Charismatic churches, etc. The majority belong to local Zionist Churches. What brings them together is their commitment to study the Bible.

The woman who was elected as leader for the two recorded Bible studies is a welleducated Anglican lay minister in her late fifties. She has led the group before and is experienced in this regard. She, like the rest of the group, was not given the text to be discussed beforehand. She therefore participated on the same level with the others, and acted merely as the facilitator. Of the 18 members that were present 16 participated in the discussions, while no one dominated. In the second study the same members were by and large present.

\section{Bible study 1: Matthew 13:53-58}

The first speaker took a clue from the heading of the pericope in the Xhosa Bible and thereby introduced the main topic of the discussion. The Xhosa word used here is dela, which means despise, or undermine (according to the translator). The main question in the discussion was why people did not consider Jesus to be "worthy". Matthew 13:57 suggest that the people of Nazareth were "offended" by what He said (in the discussion there was only one reference to this text, i.e. by speaker $\mathrm{H}$ ). In an attempt to find reasons as to why Jesus was rejected various speakers proposed a sociological reason (e.g. that Jesus was born 
in a "low place", that is Nazareth) and a psychological reason (that nobody expects somebody special to come from their own community). They also tried to ascertain who the people were that rejected Jesus: the local community who has known Jesus from childhood, his family, or perhaps also the Pharisees. Arguments were offered why even the disciples may be included among those who rejected Jesus. The group members referred to other incidents in the Gospels to substantiate this argument. Some emphasis was put on the conviction that Jesus was indeed the Son of God and not an ordinary human, as the people of Nazareth took him to be. It should be noted that this Bible study was scheduled during a period when the group was discussing Christological issues according to the Gospel of John in their normal weekly Bible School classes.

The group felt some natural affinity with the situation described in the text. Most of them have grown up in similar close-knit communities to which they go back from time to time. Their present living conditions, for example in squatter areas, also resemble such a "low place". They did not reflect on the question as to how they as members of such "low" communities would react to Jesus. Instead, they identified themselves with the position in which Jesus found himself. As religious leaders, they experience similar suspicion and rejection from their local communities and families who know them and who tend not to expect anything special of them. Jesus is regarded as an example: "...making an example by (sic) preachers on earth. And He was even more than just a preacher; he was God himself" (Speaker B). The group therefore arrived at the following conclusion: "The text gives us power", and: "We must ask God to give us strength so that even if we are confronted by these questions we can have strength."

This was a very dynamic discussion in which almost all the members participated. There was ample interaction between the group members. They challenged one another's opinions, offered further explanations and followed up earlier arguments. The youngest member of the group tried, early during the meeting, to draw the group into a discussion of the significance of the text for them but he was simply ignored. The shift towards an application of the text only occurred towards the end of the session.

The text of Matthew 13 remained central to the discussion. The clue to the meaning and focus of the text was taken from the heading, which was regarded by the group as an integral part of the text. Arguments on why Jesus was rejected were based on issues they found in the text under discussion. Other texts and biblical incidents were quoted or referred to in order to strengthen arguments. In one case a speaker was even challenged to give an appropriate Scriptural reference while another speaker apologized for not giving a reference. The method of using other Scriptural incidents by way of associating it with a particular word, phrase or idea in the text, which appears as "pearls on a string", is typical of the way the Bible is used by this group.

The world behind the text was not explicitly looked into. The fact that the incident occurred in Nazareth, which was identified as a "low place" and their experiences of "low places" (see above) helped them to spontaneously locate the text in its original setting.

In terms of interpretative strategies, the group focussed on the text and tried to get clarity on what it was about. They asked questions such as, "Who rejected Jesus?" and "Why was he rejected?" They then moved on to associate themselves with this rejection experienced by Jesus. Examples from their own experience as preachers and church leaders were quoted. One speaker referred to the way in which people tend to judge religious leaders on the basis of their conduct long before they moved into leadership positions. An example from a local Xhosa drama on radio was also referred to in this regard. This strategy led the group explicitly to regard the life of Jesus as an inspirational example that 
"gives us strength" (see above). The strategy employed here for appropriation is clearly that of analogous situations.

Two doctrinal keys may be at work in this Bible study: The focus on Jesus and on his identity that people failed to recognise comes from the Christological convictions of the group. Apart of that being the theme of their Bible School teaching at the time, it is central to the faith of many group members. The other key is the leadership positions that many group members hold in their churches. That helped them to unlock the text in a particular way for their own situation.

The group's contemporary context played an important role in their interpretation. Their spontaneous understanding of the situation described in the text was possible on the basis of their own living conditions and life experiences, as explained above. In their application of the text, explicit and particular attention was given to their role and experiences as church leaders and preachers.

\section{Bible study 2: Luke 4:16-30}

The research assistant provided the group with some input on the historical background of the text, with specific reference to the concept of the Jubilee (unyaka owamkelekileyo $w e N k o s i=$ the year acceptable to the Lord):

In verse 19 there is a reference to the "year of grace". This refers to the so-called year of Jubilee described in Leviticus 25:8-28. This was celebrated every 50 years $(7 \times 7+1)$. Those who have lost their land and therefore their means of livelihood in the past 50 years received it back in the year of Jubilee. In this way, it provided a new beginning, a fresh start for impoverished people. Likewise, the quote from Isaiah 61 emphasises the needs of the poor, the imprisoned, the blind, and the oppressed. In verse 21 Jesus explains the purpose of his own ministry in terms of the fulfilment of the Year of Jubilee.

According to Old Testament scholars there is hardly any evidence that the prescribed year of Jubilee was ever celebrated in Israel. Why do you think that would be? Do you think that the year of Jubilee indeed became a reality in the time of Jesus and as a result of his ministry? And today?

The leader announced verse 19 as the main topic for discussion. A discussion followed on the affirmation that Jesus was the fulfilment of this prophecy of Isaiah. He is the one who announced freedom to the people of his own hometown, but He was rejected because people knew who He was. It was pointed out that by saying that the Spirit of the Lord is upon me Jesus wanted people to recognise who he really was, i.e. the Son of God. Two parallel lines of argument ensued. One argument suggested that Jesus was actually quoting Isaiah on being anointed by the Spirit. It was then pointed out that Jesus, by quoting this passage, drew attention to the fact that he himself was the fulfilment of this prophecy. The other argument focused on the fact that Jesus came to the "low place" Nazareth where people were not willing to accept his preaching.

The discussion then shifted to the contents of Jesus' message and that he brought a message of delight for his people: healing for the blind and release for those trapped in slavery and poverty. This is what he was destined before his birth to do: to bring salvation to all humankind. It is when one discovers, through the Holy Spirit, who Jesus is that this year of release takes effect. Then wonderful things happen and people are astonished, like in Nazareth.

The group dynamics during this discussion was perhaps not as spontaneous as usual. It did not flow very smoothly and was not as lively or even heated as is often the case. 
Sometimes long intervals of silence, with people reading the text or paging for other passages to enlighten them, occurred. The fact that two lines of argument could run alongside one another was probably due to the fact that some people were still pondering on an issue and then voiced their ideas while others have moved on to another issue. On a few occasions people in fact said that they were not sure whether what they are about to say is indeed correct.

A strong focus on the text was obvious during this Bible study. It was almost spontaneously felt that the real contents of the acceptable year meant that release and salvation were announced. It was not so much a matter op probing the text, but "simply" of reading it. The focus on the text is highlighted by the fact that repeated references to particular verses were made. The literary context was explicitly employed. One speaker referred to the immediately preceding incident on the temptation of Jesus in order to strengthen the argument on Jesus' divine character. Repeated quotations from different parts of Isaiah by speaker $\mathrm{C}$ and other biblical references were employed to strengthen arguments. The relevance of speaker D's references was not obvious and sometimes met by the group with dismay.

The social world behind the text was mentioned a number of times, although this was perhaps more prominent in the previous Bible study. According to the group, the fact that Nazareth was a "low place" made the fact that Jesus revealed his true mission here remarkable. The input given by the research group on the Jubilee, which was intended to strengthen their understanding of the world behind this text, was conspicuously ignored, though it probably helped them to understand what "the acceptable year of the Lord" meant. It is striking that Isaiah 61 was not used to understand the notion of the Jubilee, but only to acknowledge a prophecy that was fulfilled in Jesus Christ. Other Isaiah texts were quoted to the same effect. Leviticus 25 was not even referred to.

The following interpretation strategies can be detected in this Bible study: The motifs of release and salvation were clearly viewed as physical realities. This is probably due to both the concrete understanding of faith in the African worldview and their conviction that the wonders that Jesus did could and can still occur. The fact that these were simple realities of life helped them not to spiritualise the meaning of the text, while expressions and issues in the biblical text that are not understood on face value are often spiritualised by the group. Only one speaker explicitly related the text to present experiences: "We experience the release when we as believers are no longer addicted to liquor" and "We experience this day of release when people are astonished when they see the healings (which we perform) and see that the Scriptures are fulfilled".

The most important interpretative strategy that the group employed was that of a prophecy being fulfilled. In this they found confirmation of Jesus as the true Saviour who has a physical effect on their lives. Although explicit links to present day reality are not made, their manner of speech shows that they identify with those who are beneficiaries of His announcement of the release, over against those who reject it, as represented by the people of Nazareth. The group thus "read with" the disciples as those who recognised Jesus as the fulfilment of the Old Testament prophecies, over against the people of Nazareth. They were however, not certain whether the disciples were part of the group that rejected Jesus. The strategy of "corresponding experiences" was also used. The fact that, in the experience of group members, salvation, particularly in the form of healings and release from (different types of) evils still occur today made the "acceptable year" something real and part of their life experience. 
The following doctrinal keys enabled the group to appropriate the text: 1) an interest in the fulfilment of prophecies, 2) the concrete reality of healing wonders, in the Bible and today, that is typical of the Charismatic tradition, and 3) the importance of gifted individuals who can mediate a sense of supernatural as well as physical well being in terms of an African worldview.

The fact that no explicit references to the contemporary context were made may be due to the fact that in African churches preaching very often deal with the "Biblical scenario" only. There is nevertheless a level of identification with the reality of which the text speaks, because the speakers are not really conscious of the historical gap between "then" and "now". The text simply speaks of a "present" reality, with which they can identify, particularly in this case, in terms of "common experience". 